Correction

\title{
Correction: COTI-2, a novel small molecule that is active against multiple human cancer cell lines in vitro and in vivo
}

\section{Kowthar Y. Salim ${ }^{1, *}$, Saman Maleki Vareki ${ }^{2, *}$, Wayne R. Danter ${ }^{1}$, Serban San- Marina7 and James Koropatnick ${ }^{2,3,4,5,6}$}

${ }^{1}$ Critical Outcome Technologies Inc., London, Ontario, Canada

${ }^{2}$ Cancer Research Laboratory Program, Lawson Health Research Institute, London, Ontario, Canada

${ }^{3}$ Department of Microbiology and Immunology, Western University, London, Ontario, Canada

${ }^{4}$ Department of Pathology, Western University, London, Ontario, Canada

${ }^{5}$ Department of Oncology, Western University, London, Ontario, Canada

${ }^{6}$ Department of Physiology and Pharmacology, Western University, London, Ontario, Canada

${ }^{7}$ Department of Otolaryngology-Head and Neck Surgery, Mayo Clinic School of Medicine, Rochester, Minnesota, USA

* These authors have contributed equally to this work

Published: September 01, 2017

Copyright: Salim et al. This is an open-access article distributed under the terms of the Creative Commons Attribution License 3.0 (CC BY 3.0), which permits unrestricted use, distribution, and reproduction in any medium, provided the original author and source are credited.

This article has been corrected: Dr. Serban San-Maria was added to the author list.

The authors sincerely apologize for this oversight.

Original article: Oncotarget. 2016; 7:41363-41379. https://doi.org/10.18632/oncotarget.9133 